concerned about their health, or who are concerned about their faith."

Marburger arrived at Brookhaven in 1998 in the role of clean-up man, following a huge public row over a radioactive leak that had mobilized local opinion against the laboratory (see Nature 400, 303; 1999). He soon received widespread praise for calming down what had become an ugly feud between laboratory staff and environmental activists.

Before Marburger took over, "you couldn't even get people at the lab to return your phone calls", says Scott Cullen, a lawyer for the anti-nuclear STAR Foundation, which led local criticism of the laboratory. "It was a completely adversarial relationship," Cullen adds. "He definitely changed that."

It wasn't Marburger's first experience in a hothouse public controversy: 20 years ago, he chaired a fact-finding panel on Long Island's Shoreham Nuclear Power Plant, which was bitterly opposed by activists and was eventually dismantled.

Although lacking direct authority over major research agencies, such as the National Science Foundation and the National Institutes of Health, the science adviser is the US administration's topranking official for setting science policy If, as expected, Marburger is confirmed by the Senate, he will also co-chair the President's Committee of Advisors on Science and Technology with the venture capitalist Floyd Kvamme (see Nature 410 617;2001).

Marburger received his undergraduate degree from Princeton and his doctorate in applied physics from Stanford. In the 1970s he was a department chair and dean at the University of Southern California where he co-founded a centre for laser studies. From 1980 to 1994, he was president of the State University of New York at Stony Brook, from where he also served as chairman of the Universities Research Association as it managed construction of the ill-fated Superconducting Supercollider project.

Michael Lubell, head of public affairs at the American Physical Society, calls the nominee "a good choice", and praises him for his solid understanding of science policy. But Lubell worries whether the new science adviser will obtain direct access to the president, or instead will have to work through White House staff director Andrew Card.

It is a question Marburger has asked himself. "I was interested in how the staff works to provide advice to the administration on all kinds of issues," he says. "And I was impressed with the dynamic that I found in the president's office. They work well together as a team, and the president seems to listen."

\title{
Budget proposal casts doubt over physics portal's future
}

\section{Declan Butler}

A powerful congressional committee has passed a budget bill which, if enacted, could close down PubScience, a free search service for the physical sciences literature, operated by the US Department of Energy (DoE).

The budget bill, which was passed last week by the House appropriations subcommittee for energy and water development and was expected to be endorsed by the full appropriations committee, is likely have a chilling effect on other government-operated services, including the National Library of Medicine's PubMed Central, according to some observers.

The DoE's Office of Scientific and Technical Information (OSTI) launched PubScience in 1999 to give physical scientists the kind of free, journal cross-searching facilities already offered to life scientists by PubMed. But the House subcommittee says in its bill that it is concerned that the OSTI is duplicating information services already available from commercial publishers, and urges a careful review of PubScience. This advice is likely to be heeded: "Needless to say, OSTI and DoE will be very responsive to the guidance of Congress," says Walter Warnick, director of the OSTI.

The subcommittee proposes a 2002 budget for the OSTI of $\$ 7.9$ million, $\$ 1.1$ million less than it asked for, and more than $\$ 700,000$ less than this year's budget. This cut is greater than the running costs of PubScience. Before becoming law, the entire bill has to approved by the full House, agreed with the Senate and signed by President George W. Bush.

The proposal arose after a lobbying campaign aimed against PubScience, spearheaded by the Washington-based Software \& Information Industry Association (SIIA) on behalf of for-profit and non-profit member companies including Reed Elsevier, ISI, Chemical Abstracts Services and Cambridge Scientific Abstracts.

David LeDuc, an SIIA official, says that PubScience provides a service similar to products offered by the association's members, and "makes it increasingly difficult for these private-sector companies to continue offering their products". He says that government initiatives should confine themselves to providing access to government information, and not act as secondary publishers.

Arie Jongeman, managing director of Elsevier Science's physical sciences division, says that the subcommittee's proposal means that "people have come to their senses; sanity is prevailing". He claims that services such as PubScience are often less efficient than outsourcing, and that their true costs can be

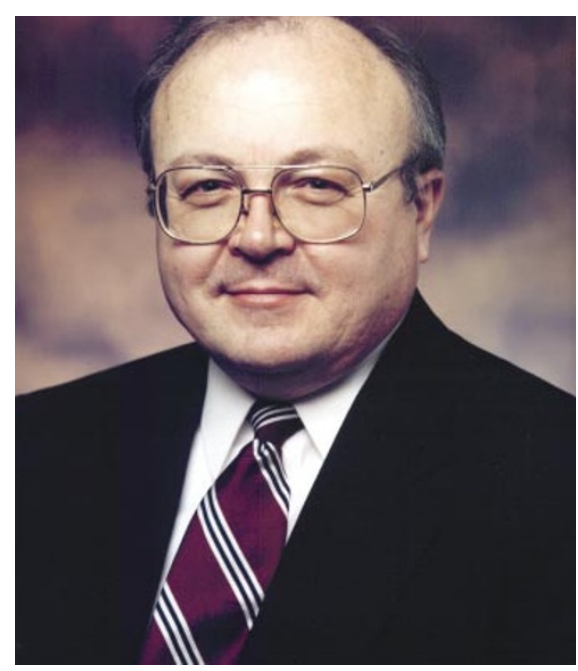

Open to suggestions: Walter Warnick says he will take the congressional advice seriously.

concealed. Jongeman adds that the appropriators' action "is an important signal that this kind of US governmental support is something which is dangerous and can flip back to zero overnight".

But one DoE official argues that PubScience is "well anchored in law", noting that the department's mission explicitly includes the dissemination of scientific information.

And Martin Blume, editor-in-chief of the American Physical Society, which has extensive publishing interests, says that PubScience is not in competition with these "any more than the National Library of Medicine, MedLine, and PubMed are". He adds: "The concern of the appropriators is not justified."

But the SIIA is widely expected to attack PubMed next. The better-established lifesciences service, however, may prove to be a difficult target, as the National Library of Medicine, which operates it, has very strong support in the Congress.

There are signs, meanwhile, that the government's role in scientific publishing is becoming a partisan issue. In May, Joe Lieberman (Democrat, Connecticut), chair of the Senate Committee on Governmental Affairs, introduced a bill that would give federal research agencies an explicit mandate to carry out PubScience-like activities. The act explicitly states that agencies should develop websites with links to the servers of outside publishers. The contrast between the two measures would appear to set the stage for a conflict on Capitol Hill between Democrats, who control the Senate, and Republicans, who control the House.

http://pubsci.osti.gov http://www.siia.ne

http://www.nature.com/nature/debates/e-access 